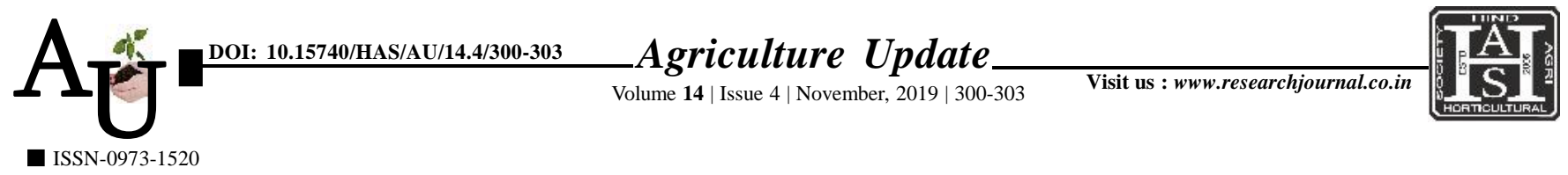

\title{
Research Article: Assessing the knowledge level of tribals farmers on recommended indigenous agricultural practices in millets
}

K. Velavan and M. Natarajan

Article Chronicle: Received : 29.08.2019;

Revised : 09.10.2019; Accepted : 16.10.2019

KEY WoRds: Indigenous agricultural practices, Millets, Assessing knowledge level, Tribal farmers, Kalrayan hills

Author for correspondence :

\section{K. Velavan}

Department of Agricultural, Extension, Annamalai University, Annamalai Nagar, Chidambaram (T.N.) India See end of the article for authors' affiliations
SUMMARY : The present paper is the outcome of an attempt to made a document of indigenous practices, which are used by tribal people of Kalrayan hills in Villupuram district of Tamil Nadu. This paper gives an account of millets crops viz.,Varagu, Cumbu, Samai, Thinai. Their traditional belief, concept, knowledge is the cause of sustainable agricultural development. This paper deals with the account of indigenous agricultural practices with their knowledge level of the tribal farmers in Kalrayan hills. A sample size of 300 respondents is selected by the proportionate random sampling method. The practices were selected by the pre testing interview schedule and the date was analyzed by appropriate statistical tools. This paper argues that the need to identify the indigenous knowledge which has scientific rationality, so that it can be incorporated into agricultural especially in millets. It also deals with the constraints of suggesting the knowledge in the study area and the strategy for using indigenous knowledge in millets to get food security, livelihood and ecological balance on a sustainable development in the tribal sectors. The result examined that most of the tribal farmers had high knowledge in indigenous agricultural practices on millets in Kalrayan Hills.

How to cite this article : Velavan, K. and Natarajan, M. (2019). Assessing the knowledge level of tribals farmers on recommended indigenous agricultural practices in millets. Agric. Update, 14(4): 300-303; DOI : 10.15740/ HAS/AU/14.4/300-303. Copyright@ 2019: Hind Agri-Horticultural Society. 